Fall 1997

\title{
The Art of Fasting: Benin's Ague Ceremony
}

\author{
Kathy Curnow \\ Cleveland State University, k.curnow@csuohio.edu
}

Follow this and additional works at: https://engagedscholarship.csuohio.edu/clart_facpub

Part of the African Languages and Societies Commons

How does access to this work benefit you? Let us know!

Publisher's Statement

(C) 1997 James S. Coleman African Studies Center, UCLA

\section{Recommended Citation}

Curnow, Kathy. "The Art of Fasting: Benin's Ague Ceremony." African Arts 30, (September 1997): 46-53. Art Full Text (H.W. Wilson), EBSCOhost. Web.

This Article is brought to you for free and open access by the Department of Art and Design at EngagedScholarship@CSU. It has been accepted for inclusion in Department of Art and Design Faculty Publications by an authorized administrator of EngagedScholarship@CSU. For more information, please contact library.es@csuohio.edu. 


\section{The Art of Fasting: Benin's Ague Ceremony}

KATHY CURNOW

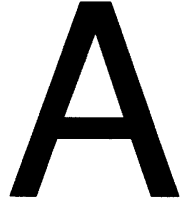

gainst all advice, Acting British Consul-General James $R$. Phillips insisted on visiting Benin City in early January 1897. The Oba had asked him to delay because of Ague, a ritual requiring his complete isolation from visitors. Although the subsequent British colonization was probably inevitable, Ague's timing and Phillips's obstinacy catalyzed the chain of reactions which led to the conquest of the kingdom.

Formerly a ceremony of critical importance, Ague has received little scholarly attention, perhaps because its full celebration ceased during the reign of $\mathrm{Oba}$ Eweka II (r. 1914-33). In its development it confirmed the Edo adage "Every new Oba creates new rules," 1 for Ague changed substantially under various monarchs, until ultimately it came to knit together such disparate elements as Lenten denial and regional New Yam beliefs. These successive royal innovations suggest that other Benin festival "traditions" may have similarly dynamic, complex histories.

Yams, Benin's staple food and crop, were ostensibly at Ague's core, but its ultimate concerns were the ownership, pollution, and sanctification of the land. Before the British invasion, yams played a ritual role in four related ceremonies. In the first, which opened the agricultural cycle, yams were planted in a symbolic pattern at the Oba's Ugbeku village farm. Diviners examined this yield to forecast the general harvest, sometimes ordaining human sacrifices to avert disasters (Thomas 1918:138-39). The second ceremony took place after the general harvest with the commencement of Ague-Osa, a period of fasting that required participants to abstain from eating newly harvested yams. ${ }^{2}$ At its conclusion, Benin's New Yam festival was celebrated, ${ }^{3}$ and budded yams were offered to paternal and maternal ancestors, deities, the unburied dead, and

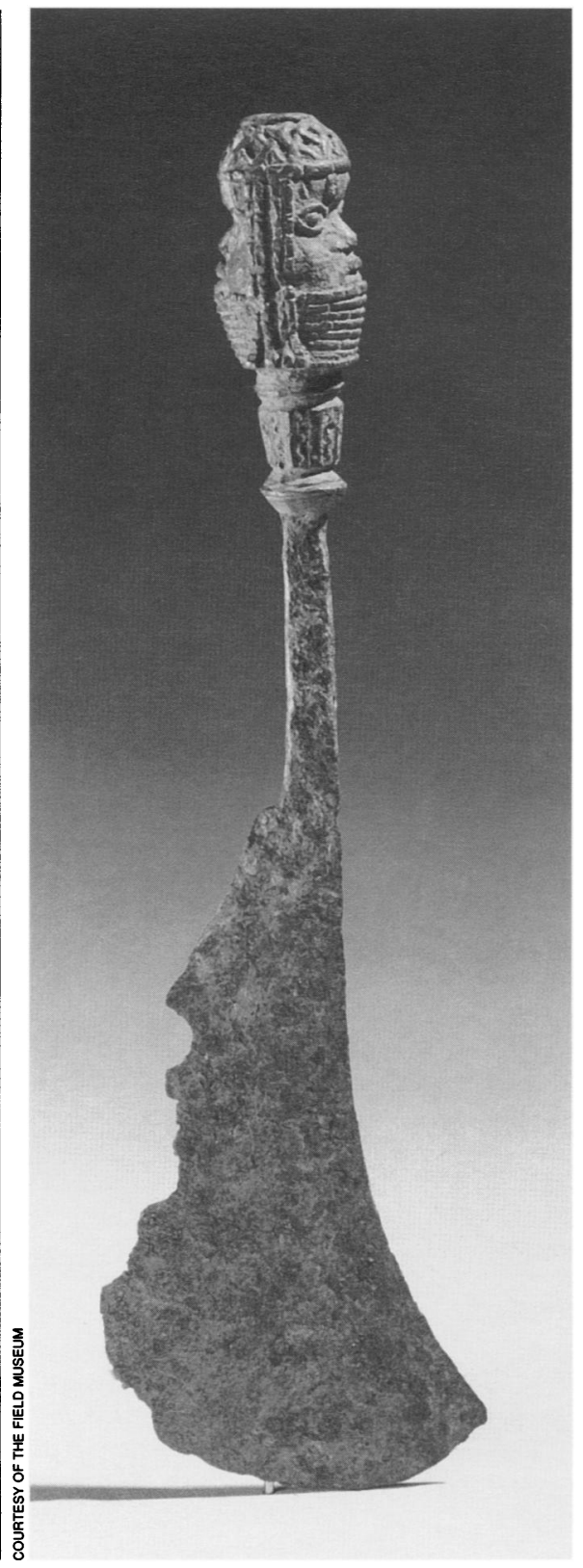

hostile spirits (Melzian 1959:99) (Fig. 1). The fourth ceremony, a second Ague period known as Ague-Oghene, followed, ending the agricultural year. By the 1930s Ague-Ohene's activities were already obscure (Melzian 1959), and the two Agues are often confused and conflated today.

Ague was a sober time. No burials or marriages took place, no guns were fired, and no drums or calabash rattles were played. While all Edo avoided eating new yams, only the Oba and certain chiefs, priests, and courtiers were full Ague participants. Their abstinence extended to other types of fresh produce ${ }^{4}$ and to sexual celibacy for up to four "Benin months." Ague-Osa's preparatory period concluded with seven days of isolation in Oguan, a special palace chamber sited in or near Oba Esigie's quarters (Nevins 1928:9; Bradbury notes 1959:BS218). ${ }^{6}$ Human sacrifice took place on the chamber's threshold when the Oba was about to enter, and again just before his exit (Egharevba n.d., "Benin Museum Catalogue" ms. in Bradbury notes:R67).

Other injunctions besides fasting were in effect. One chief told me, "On certain days you don't talk to human beings; you don't touch water at all, even to gargle or bathe." Perils were intense, even lifethreatening. Contact, direct or indirect, with the new yam or its leaf was contaminating. As Chief Osuan said, "If [partici-

Left: 1. Yam knife with handle terminating in a Janus memorial head. Bronze, $19 \mathrm{~cm}\left(7.5^{\prime \prime}\right)$. The Field Museum, Chicago, neg. A99487, cat. 210309.

This type of knife was used to peel sacrificial yams for the palace's New Yam festival.

Opposite page: 2. Bronze plaque representing the Oba with attendants. 16th century. National Museum, Lagos.

The attendants are chiefs Osa and Osuan, who kneel only when praying with the Oba at Ague. 
pants] touch a new yam plate or shake a new yam hand or have any contact with something associated with new yam, they won't come back safe from Ague." A deadly cholera-like disorder was said to strike those who did not comply with Ague's regulations.?

Participants suspended metal badges (umanague or $a b a$ ) from a length of twine around their necks. Some were wedgeshaped, like miniature "thunderbolts" (ugh-avan), while others were cruciform. ${ }^{8}$ The expression "Because he was unable, he did not wear the $a b a^{\prime \prime}$ describes someone who cannot finish what he starts. A lapsed participant stricken with the cholera-like illness prompted the phrase "Umanague has caught him."9

Ague's self-denial and isolation kept participants free from pollution, strengthening their spiritual powers and making them especially pleasing to the ancestors. Chief Obasogie stated that without Ague's sanctification, those attempting certain invocations risked death; successful fasting was believed to ensure that all requests would be granted. Recognition of the supernatural potency Ague conferred often led to court and military promotions.

\section{Ague's Origins}

The new yam harvest is celebrated because it signifies ancestral endorsement, a certification that the world is as it should be. Privation, disease, and other disasters are evidence of problems with Oto, the deified earth. Ague's origins seem tied to such afflictions. Epidemics and famine are said to have occurred during the early years of Benin's present, Ife-founded dynasty, confirmation that the land was polluted. Tradition states that the royal settlers sent to Ife for the deities Uwen and Ora, also known as the Ebo n'Edo ("Edo gods"), 10 to arrest these calamities. These gods' appeasement before eating new yams acted as a sort of proto-Ague.

Land concerns continued under Oba Ewedo (r. ca. 1330-60). When he finally established control over Benin City itself, he was forced to "buy" occupancy rights ceded by Chief Ogiamien, descendant of a previous indigenous regent. This transaction must be duplicated at each installation. When the Oba purchases Ogiamien's sand during his coronation (Nevadomsky 1984:56), he acknowledges his own external origin and affirms land ownership as the birthright of the indigenous inhabitants. The spiritual authority to rule requires their ancestors' endorsement.

Despite this ostensible settlement, the struggle between settlers and indigenes is considered perpetual. Ominigbon, Benin's divination system, describes their relationship metaphorically: "The human world fought for the palm fronds and the spirit world fought for sugarcane." 11 The interpretation of this epi- gram deals with either a dispute that continually resurfaces or with disease and epidemics. Through this association of eternal struggle with disease, the epigram reinforces ties between concepts of land ownership and land pollution.

Approximately a century later, Oba Ewuare (r. ca. 1450-80) blamed the deaths of his two sons on "spoilt" land. Hoping to purify the land and forestall additional problems, he passed laws prohibiting bathing, sex, dance, and celebration, thereby introducing mourning as part of the appeasement of Uwen and Ora. Ewuare is credited with coalescing the ceremony known as Ague-Oghene.

The name Ague-Oghene, "the Ooni of Ife's Ague," refers to the origin of the dynasty and its gods Uwen and Ora. Ewuare appointed priest-chiefs to care for these deities: Chief Osa is in charge of Ora, who seems to be associated with weapons and aggression, while Chief Osuan cares for Uwen, whose province is healing, obstetrics, and fertility of the soil. Each chief has a shrine to his respective deity, but the joint Ebo n'Edo altar is in the palace, where worship of these gods is restricted to a small circle.

The popular saying "Only Osa and Osuan know the secret of the young palm fronds"12 intimates that these chiefs are privy to some of the palace's most secret matters. Sometimes called the "twins" (iv'eva, or "two coconuts"), they always appear together (Fig. 3), and the saying "The ceremony the Oba opens finds Osa and Osuan there" attests to their critical presence. ${ }^{13}$ These chieftaincies were formerly associated with human sacrifice, the bathing in or drinking of human blood, and even cannibalism, a concept that was anathema to the Edo. The current Chief Osa noted

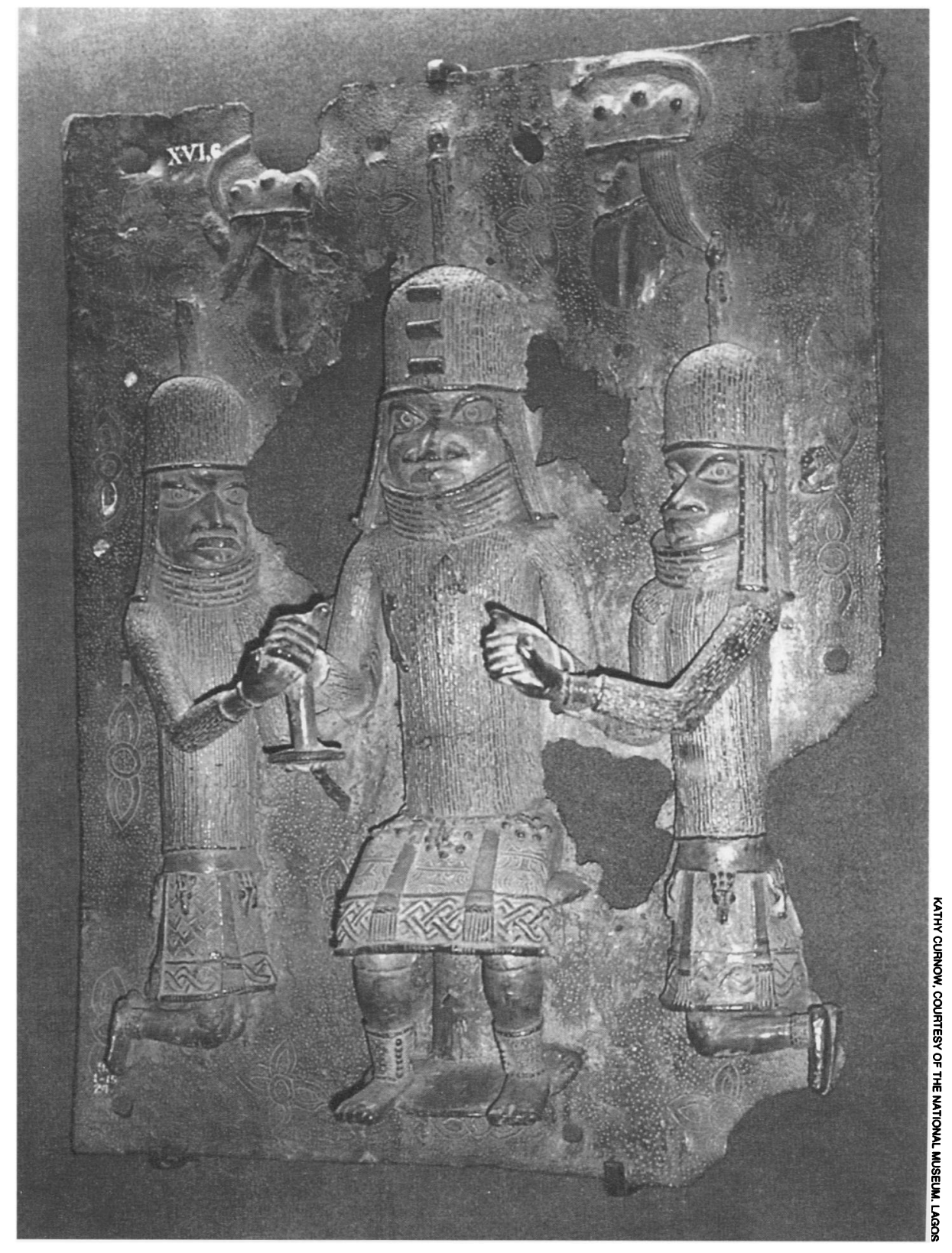




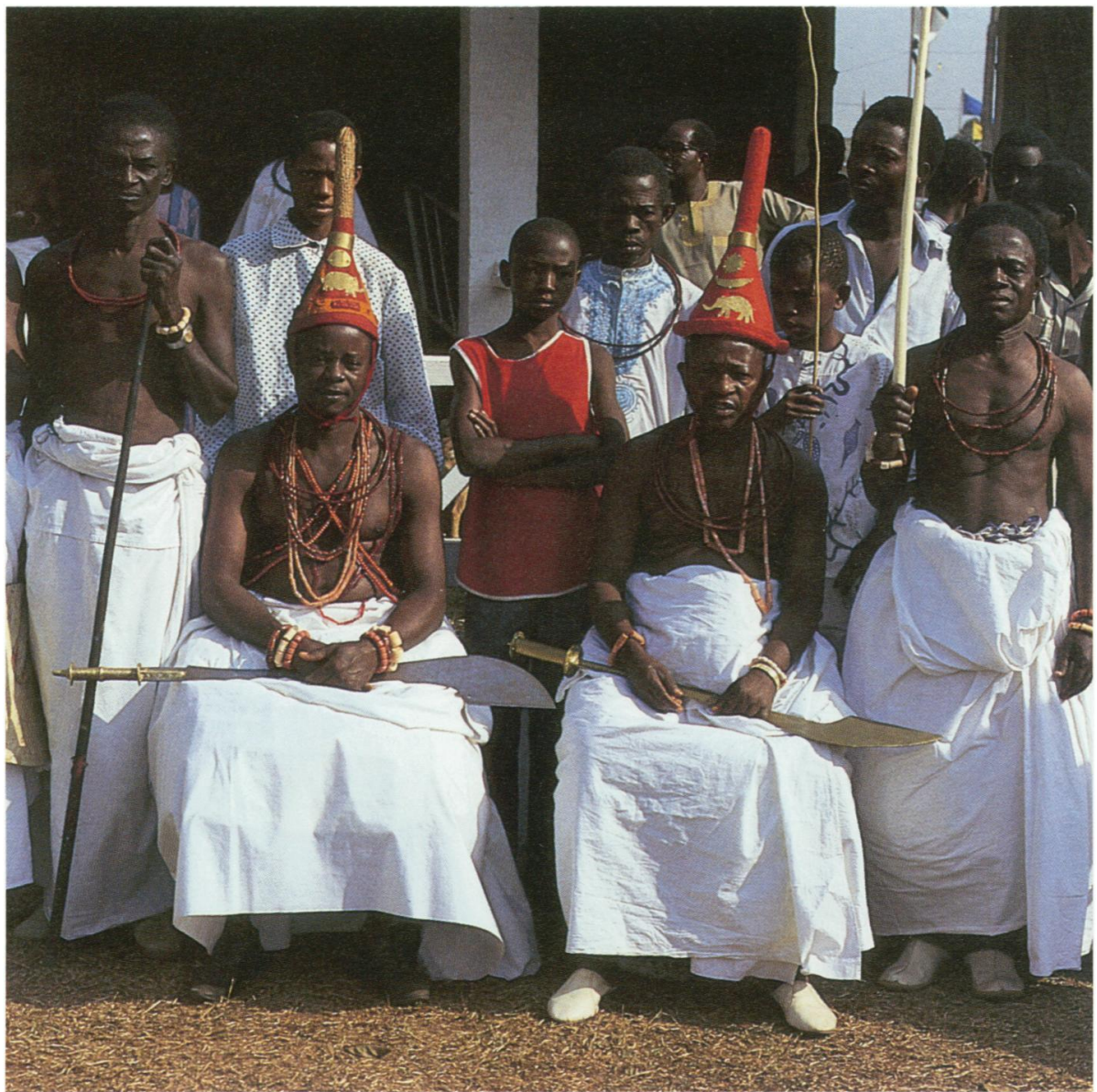

his predecessors' appellation: "Osa has killed and eaten a victim; the son of one who eats flesh greedily." The Ebo n'Edo were similarly praised: "The deities who don't eat sick victims." 14

\section{Oba Esigie and Ague-Osa}

Oba Esigie (r. 1517-66) drastically changed Ague's focus, although chiefs Osa and Osuan remained critical participants. His alterations reflect the growing presence of the Portuguese in the early sixteenth century. Their wealth and arms stimulated interest in their religion, along with the hope of increased trade, military alliances and supplies, and perhaps additions to the supernatural arsenal. European records suggest that Esigie was baptized as a youth in 1516 and came to the throne the following year (Ryder 1969:50-51, 69-73). His accession involved an intense struggle with his elder brother, Arhuaran, and he seems to have recruited Portuguese allies even before the death of his father, Oba Ozolua (r. ca. 1490-1517). One well-known Edo account hints at a surreptitious relationship. When his father queried him about his foreign associates, he dissembled, "I don't understand them. When they tell me miniminimini (nonsense syllables referring to Portuguese's unintelligibility), I answer miniminimini."15 Individual Portuguese did assist him in his early struggles for the throne (commemorated in the Iron ceremony) and helped him defeat the Igala during the Idah war.

Christianity initially prospered under Esigie. The Edo state that three shrines to the Supreme God Osanobua were originally Catholic churches, erected during his reign. Esigie rededicated Ague, christening it Ague-Osa ("the Supreme God's Ague"), and changed the ceremony's direction. Many contemporary chiefs say that Ague was "just like Lent," and Jacob Egharevba asserted that Esigie "copied it from the Catholic Church" (in "Benin Museum Catalogue" in Bradbury notes: R67).

Although at first Lent seems unrelated to Ague-their scheduling and prohibitions differ-both ceremonies do focus on purposeful self-denial and sacrifice. Esigie's Ague innovations included the new emphasis on Osanobua and the transformation of the Ugbague grove into a preparatory arena for prayer, penitence, and meditation. ${ }^{16} \mathrm{He}$ also originated the final seven days of seclusion in Oguan, whose chamber was sited by his quarters, and introduced the umanague badge, granting it only "to those of highest character." He mandated that its wearers never be killed (Bradbury notes 1951:A35).

Some bronzes which probably portray Esigie demonstrate Ague connections, and date from either his reign or that of his son, Oba Orhogbua. Foremost
Left: 3 . Chiefs Osa and Osuan wearing contemporary versions of the headdresses with oro projections seen in the plaque in Figure 2. Benin City, ca. 1986. Photo: Joseph Nevadomsky.

Opposite page: 4. Plaque. Bronze, $45.5 \mathrm{~cm}$ (18"). Reiss-Museum, Mannheim, Völkerkundliche Sammlungen, IV Af 3107. Purchased in 1925.

The legs of the helmeted Ewa figure at lower left suggest the turned-up legs of the royal mudfish figure.

among them are a series of six plaques ${ }^{17}$ showing essentially the same scene: the Oba seated on a cylindrical throne, holding an iron hammer (avalaka or avanaka)) in his right hand, and flanked by two kneeling chiefs (Fig. 2). All three wear beaded attire and headgear topped by projections known as oro. On four of the works, the chiefs support the Oba's hands, as is usual when the Oba is moving at ceremonies. On the other two, a matched pair that seems slightly earlier (one in the National Museum, Lagos, and the other in the British Museum), they do not touch him. Five of the works include small profiled Portuguese halffigures or heads near their upper edges. These fragmentary figures ${ }^{18}$ occur on many plaques; they are decorative motifs, not meant to be read as part of the scene. Although generally the Portuguese symbolize wealth (two figures hold manillas, curved metal bars which served as currency), they may also indicate events from Esigie's reign.

The symmetrical compositions are near duplicates of one another. The Oba remains rigidly frontal, while the others turn. This implication of movement has foreign origins, deriving from the Portuguese and their illustrated books. Incompletely absorbed, this pose creates some awkwardness. From the hips down, the kneeling figures are nearly in profile, but their upper bodies rotate to indicate threequarter views. In the Lagos and British Museum pieces, this clumsily forces the inner arm into visibility. Hierarchical scale is less prominent than in most Benin works. The chiefs, if standing, would approach the Oba in height, differing only in the breadth of their faces and bodies. This factor, as well as their nearly identical dress, suggests very high rank.

The figures are represented wearing beaded shirts, the high odigba collar, anklets, armlets, and similarly shaped crowns, although the Oba's includes additional cylindrical ornaments. All three oro projections, woven from a special palm fiber, are clearly phallic in form; the monarch's version is portrayed as coral-covered. Oro seems to have sacral rather than political associations. Today the Oba, chiefs Osa and Osuan, the Uzama chiefs, and certain high priests (such as the Ohen Nukoni) wear oro; sixteenth-century plaques show that its use was once more widespread. 
Knee-length garments hung with pendants at the waist complete the figures' dress. Two examples show the Oba with human-face pendants, while the others depict leopard faces. His attendants wear crocodile-head ornaments except for one example, which substitutes frog pendants. The men's skirt-like garments, tied with fringed sashes, are unlike the wrappers seen on most plaques. Each has an interlace border-a mark of high statusas well as a variety of other patterns. Wrappers on the matching Lagos and British Museum plaques additionally include highly abstract frontal and profiled Portuguese faces.

The posture of the flanking figures identifies both the chiefs shown and the occasion itself. According to the present Chief Osuan, the only time he and Chief Osa kneel is when they pray with the Oba at Ague. "During Ague we dress like the Oba, but his crown is made of beads; ours is woven. We flank him then. It is a time of sober reflection...it's [we] three who can enter in the interior of Ague [Oguan] for the final seven days. [We] pray for the nation. It's like a retreat."

That the Oba himself is not shown kneeling is unsurprising. Considered submissive, kneeling is suitable for women but not men; at times of sacrificial anointing, blood is touched to men's knees with the prayer "May you not have to kneel and beg." The degradation of kneeling is one of the components of Ague that make chiefs regard it as an ordeal. There is a possibility that the royal mudfish-legged figure that is so common in Benin art might be an encoded representation of a kneeling Oba; a plaque in the Reiss-Museum, Mannheim, includes an unusual kneeling figure of a member of the Ewa guild, his peculiarly bent legs curving up like mudfish-leg representations (Fig. 4). ${ }^{19}$ Kneeling is, of course, also the Catholic position of supplication and petition.

Two additional plaques which show the same triad standing (The Field Museum, Chicago, CNHM 8258; also British Museum 98.1-14.27) are closely related to these six works. They also show Osa and Osuan supporting the Oba's arms, an activity which takes place not only at Ague but also at the Oba's coronation, his visits to Aruosa (one of Osanobua's shrines), and the Ododua masquerade (Egharevba 1934:93). Although both sets of plaques depict these chiefs identically, their traditional placement distinguishes them: Osuan is always at the Oba's left, Osa at his right. These plaques again depict similarly sized figures in nearly interchangeable attire; the source of this parity may be one of Osa and Osuan's praise names: er'Oba (eree $\mathrm{Oba}$ ), or “Oba's equals/friends."

The plaques of the standing triad also show the Oba holding an avalaka. This iron implement, whose name means

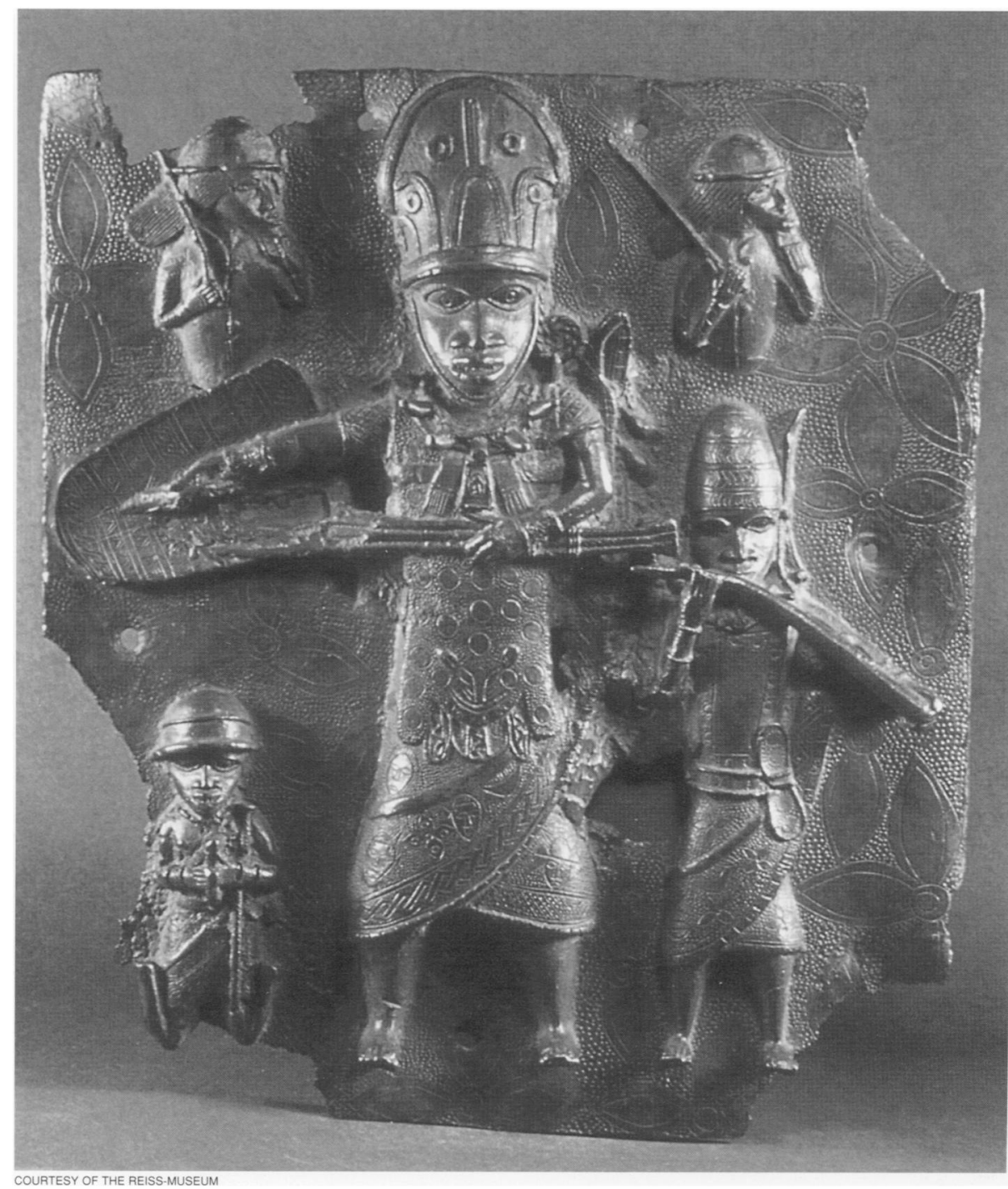

"thunder imitator," is prominent in Ague imagery. Often kept on shrines to Ogun, the deity who embodies metal and war, it is both tool and weapon: it can clear paths, destroy, or act as ise vberigho, an object which ensures that what the Oba swears on it will come to pass. The plaques may represent avalaka in any of these functions: ridding the Ague arena of danger and obstacles, killing the sacrificial victims, or reinforcing the Oba's will (particularly likely, since one of Ague's purposes is to strengthen his blessing and cursing abilities). They may alternatively specify Oba Esigie, since two of his defeated enemies, his brother Arhuaran and the Attah of Idah, were associated with avalaka.

According to brasscaster James Ihama, "Among Ogun's children, avalaka is the first son. When Ododua wanted to become very powerful, he had to invite him. Without Ogun you cannot war...in those days [when they did] sacrifice, it is this avalaka which [would] be used to kill them." It once may have had a ceremonial purpose; Chief Osa states that his founding ancestor came from Ife "with three avanaka-one for himself, one for the Oba and one for the Ine of Igun...avanaka was used for $a d a$ and eben [ceremonial swords] in those days."

The avalaka also links the plaques' Oba to the Ebo n'Edo shrine. Despite Catholic influences, Ague's associations with the deities Uwen and Ora must have continued under Esigie, since their priests appear prominently with the Oba on the Ague plaques. Esigie expanded the number of groups admitted to the Ebo n'Edo altar, which is in the palace's Ogun chamber (Iwogun) (Ben-Amos in Blackmun 1984:355). ${ }^{20}$ His newly created Ewa (the guild which, under Chief Ohuoba of Ogbelaka, traditionally woke the Oba and performed rituals before his morning zematon ceremony) joined Osa, Osuan, and the Ooton (who open and close ceremonies, using whips to keep onlookers away from secret activities) ${ }^{21}$ and Emu iru guilds (who carry brass vessels filled with protective medicine related to Uwen and Ora, according to Oba Akenzua II in Bradbury notes 1958:BS96). The frequent appearance of members of these guilds in artworks dat- 
ing from the sixteenth to nineteenth centuries attests to their importance.

Ewa members are particularly common in Benin art, seen in over fifteen freestanding sculptures (Fig. 5) as well as on plaques, altarpieces, and ivory tusks. They are usually shown with avalaka in their left hands and a staff in their right, 22 wearing helmets and a cross at the neck. Although they bear citizens' tattoos on their chests, many also have puzzling, non-Edo "cat-whisker" cheek scarifications. Visual evidence supports Oba Akenzua II's identification of these figures as Ewa (Bradbury notes 1959: BS207/2), although they have been variously labeled "messengers from Ife" and Osanobua's Ohensa priests. ${ }^{23}$ Multifigured compositions prove their low rank, for their relative size is often very small (Fig. 4). Crosses do not distinguish the wearers either, for Ewa, Ife "messengers," and Ohensa all possessed them. ${ }^{24}$ Context further suggests they are neither Ohensa nor "messengers"; they usually appear on ivory tusks in conjunction with the others who had access to the Ebo n'Edo shrine (see Blackmun 1984), and several eighteenth- and nineteenthcentury Queen Mother (Iyoba) altarpieces group them with her war chiefs and other attendants. Since the Iyoba, like her son, celebrated zematon daily (Bradbury notes 1961: BS459), it is quite likely that she had her own Ewa guild.

There are some indications that the Idah war links Ewa with Ague. One story states that Ague took place in the war camp, perhaps to fortify the soldiers. 25 The defeated Attah and his men were made to "kneel and repent," and the Portuguese who accompanied Esigie then baptized them - the climax of AgueOsa. Certainly, some of the vanquished Igala soldiers were castrated ${ }^{26}$ and taken to Benin as Eguadase guild members, serving either in the Oba's harem or at the Iyoba's Uselu palace. These eunuchs were also known as "eru errie n'Oguan," a name which ties them to the Ague site.

Bradbury recorded an ekasa song verse: "Eguadase and Ogbelaka both provide ewa; Eguadase have an altar for Esigie" (notes 1951:65). Those Ewa drawn from Eguadase were thus originally Igala, and may be the source of the Ewa figures' "cat-whisker" marks, for those scarifications were found among the Igala. Both the Oba and the Attah of Idah were identified with leopards, ${ }^{27}$ and one of the Oba's main praise names is ekpen n'owa ("leopard of the house"). To avoid potential blasphemy (because of the word ekpen's royal associations), the leopard has a second Edo name-atalakpa-which designates only the wild animal. A Benin joke refers to the defeat of the Attah, who was taunted by soldiers: "You claim to be ekpen, but you can't be-our Oba is the ekpen. You, Attah, were tricked into believing Benin would attack you, and

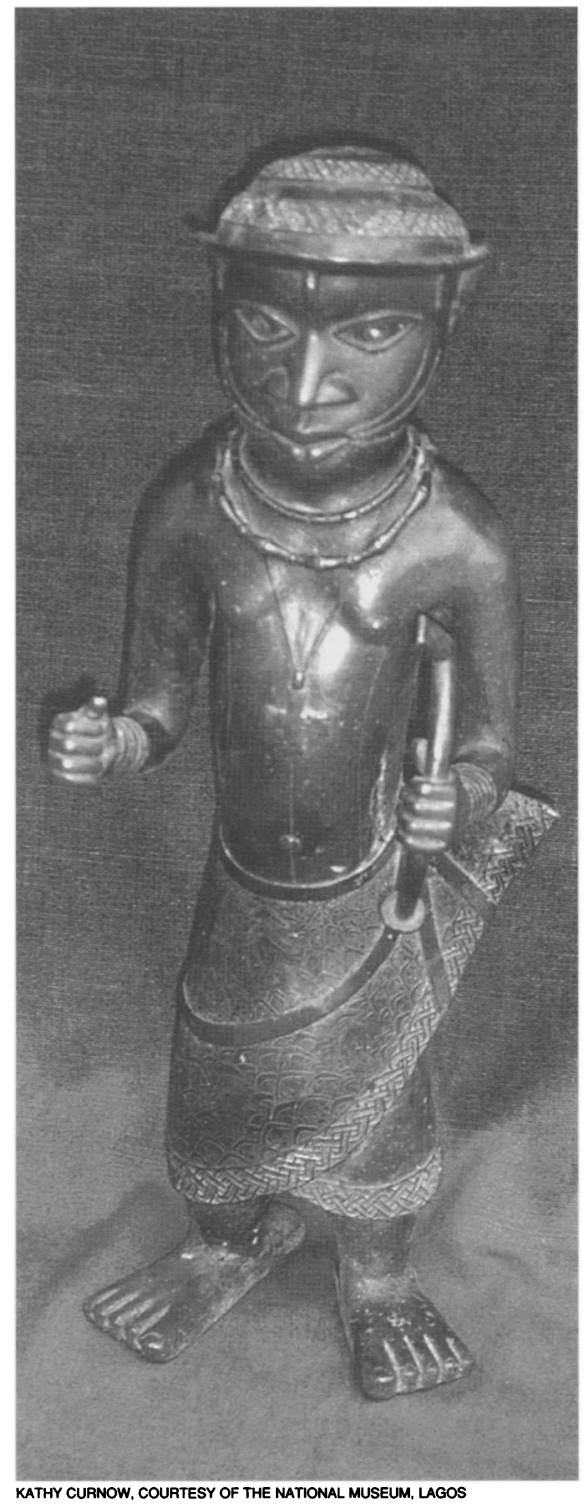

you were senseless enough to have believed it. You are a fool (akpa). You are not ekpen, you are Attah n'akpa ("Attah the fool," a play on "atalakpa")."

The Idah baptism and atalakpa stories may be apocryphal, but they are intriguing nonetheless for their insights into contemporary Edo takes on history. The possibility that baptism was the culminating rite of Esigie's Ague remains speculative, but it would provide a real tie to Catholicism (making sense of the Lenten remarks), since converts traditionally prepare during Lent for their baptism on Easter. Some adaptation of foreign religion, possibly as a key to Portuguese wealth and arms, certainly occurred in Esigie's reign, although it may not have followed orthodox conventions. One important Ague ritual did involve water; Bradbury stated, without elaboration, that a pair of ram aquamaniles (Fig. 6; also British Museum 1954Af23.294) were used in the ceremony (notes 1959: BS250). According to Chief Aragua, whose title derives from the Portuguese word for
5. Figure representing a member of the Ewa guild, wearing the distinctive costume and cat-whisker facial markings. Bronze, $63.5 \mathrm{~cm}$ (25"). National Museum, Lagos.

water, these objects functioned in Ague's closing rites and held water stored from the year's final rain (usually in November or December). The ram's iconographical significance in this context is unclear. A symbol of stubbornness and masculinity, it was only one of several types of animals sacrificed during Ague; unfed rams remained in Oguan during Ague-Osa's final seven days (Egharevba, "Benin Museum Catalogue" in Bradbury notes:R67).

Esigie's relationship with the foreigners and their religion seems to have soured with time. In 1538 the Portuguese king sent missionaries to Benin, but the ruler (who seems still to have been Esigie) was antagonistic toward them and refused to allow them to baptize anyone. They complained of human sacrifices and "idolatry" (Ryder 1969:69-73; 1961:238-39). One of Bradbury's informants claimed that Esigie killed some missionaries and took their crosses (Bradbury notes 1959:264). Although no European archival record of this exists, by mid-century some unnamed outrage prompted the Portuguese factor to suspend trade between São Tomé and Benin (Ryder 1969:74).

\section{Revival and Changes under Eresonyen}

After Esigie's reign, Ague practices shifted. His son, Oba Orhogbua (r. ca 1566-86), probably continued Ague-Osa, since he is said to have been a Catholic, but his successor, the anti-Christian Oba Ehengbuda (r. ca. 1586-1616), scrapped Ague-Osa and revived Ewuare's Ague-Oghene. In 1725 some version of Ague was still being celebrated; until his seven-day seclusion ended, Oba Akenzua I (r. ca. 1714-34) confined the Dutch factor to Ughoton port (Ryder 1969:172).

When Oba Eresonyen (r. ca. 1737-50) came to the throne, Ague underwent both revival and change. Whether because of divination, war, epidemics, or other factors, Eresonyen reintroduced Ague-Osa, Oba Esigie's Ague, meshing it with Ague-Oghene. A proverb resulted: "Eresonyen found a place to put AgueOsa." 28 One possible impetus may have been Esigie himself; Eresonyen apparently felt a keen affinity with his ancestor (Ben-Amos 1984). Trying to emulate or outdo him, Eresonyen instigated a resurgence of bronzecasting, even commissioning a more elaborate version of Esigie's erhe stool. As in Esigie's time, Catholic missionaries entered Benin (after a period when Dutch and other Protestant traders had been on the ascendance), and although Eresonyen did not 


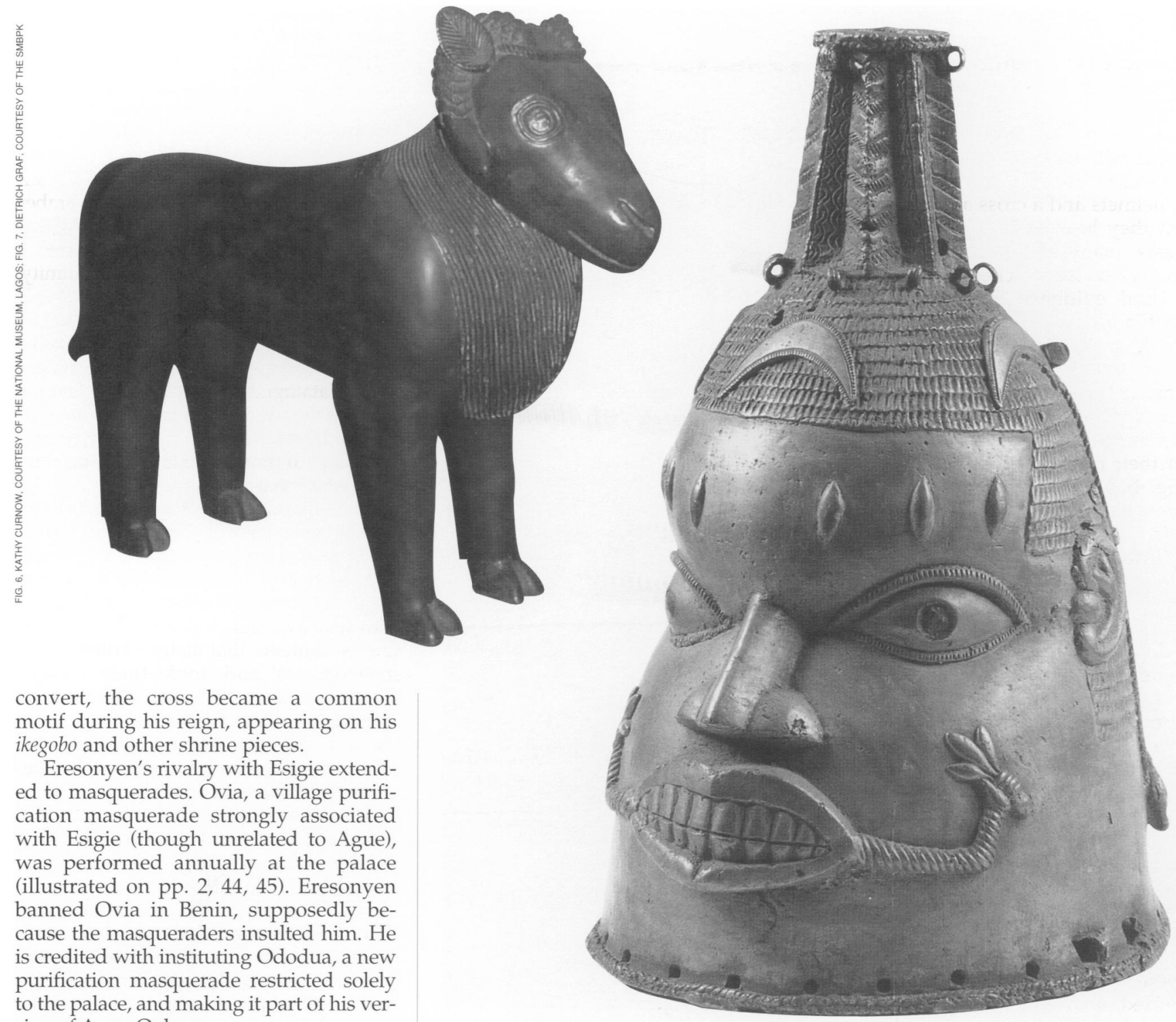
sion of Ague-Oghene.

Ododua's aristocratic materials - eagle feathers, bronze, and red ododo cloth (Figs. 8, 9) — supplanted Ovia's red parrot feathers and humble raffia. Likewise, royal aggrandizement replaced Ovia's village focus; even its name ties it to the present dynasty's origins-and thus AgueOghene-since Ododua founded Ife's kingship. The masquerade is attributed to Uzala, a village north of Benin, where

\section{Clockwise, from top left:}

6. Ram aquamanile. Bronze, length $44 \mathrm{~cm}$ (17.3"). National Museum, Lagos.

Aquamaniles were used in Ague's closing rites. Except for a second example in the British Museum, all other known examples are in leopard form.

7. Ododua headpiece. 18th century. Bronze, $33 \mathrm{~cm}$ (13"). Staatliche Museen zu BerlinPreussischer Kulturbesitz Museum für Volkerkunde, IIIC 8060.

8. Ododua masqueraders. This purification masquerade was instituted and incorporated into Ague by Oba Eresonyen. Benin City, ca. 1955. Photo: Peter Morton-Williams.

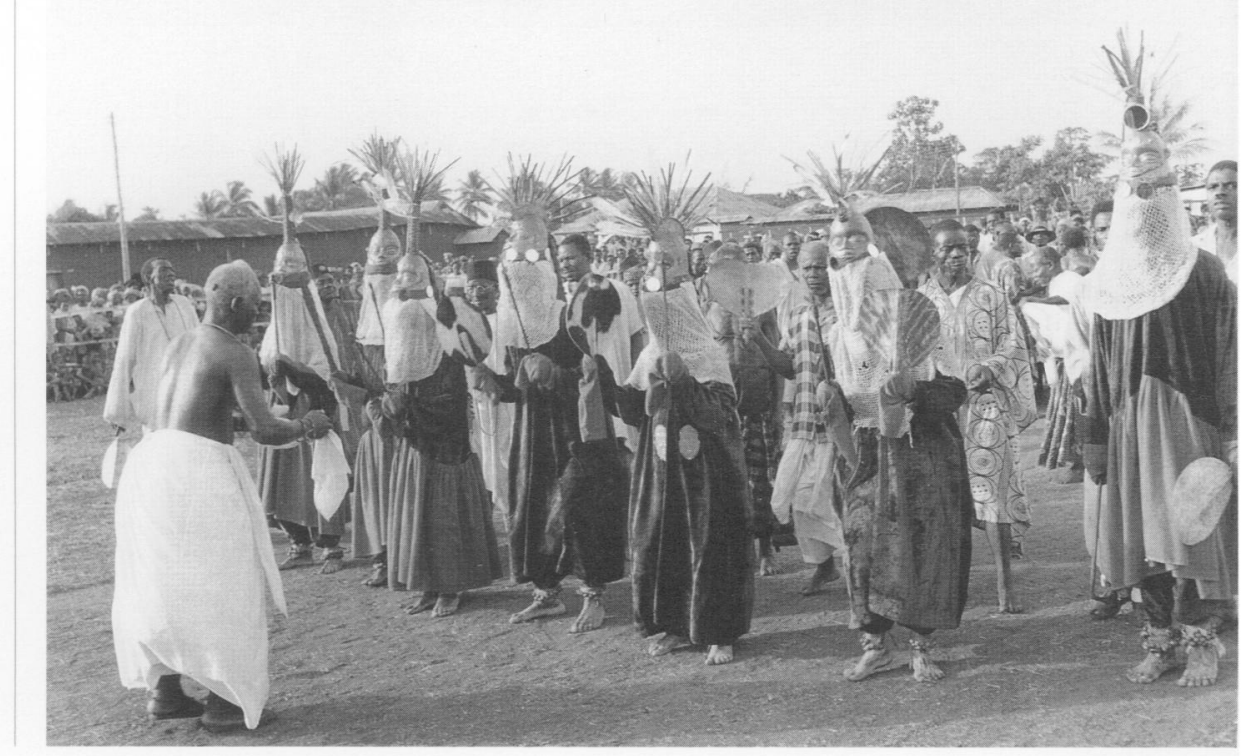

atrican arts · autumn 1997 


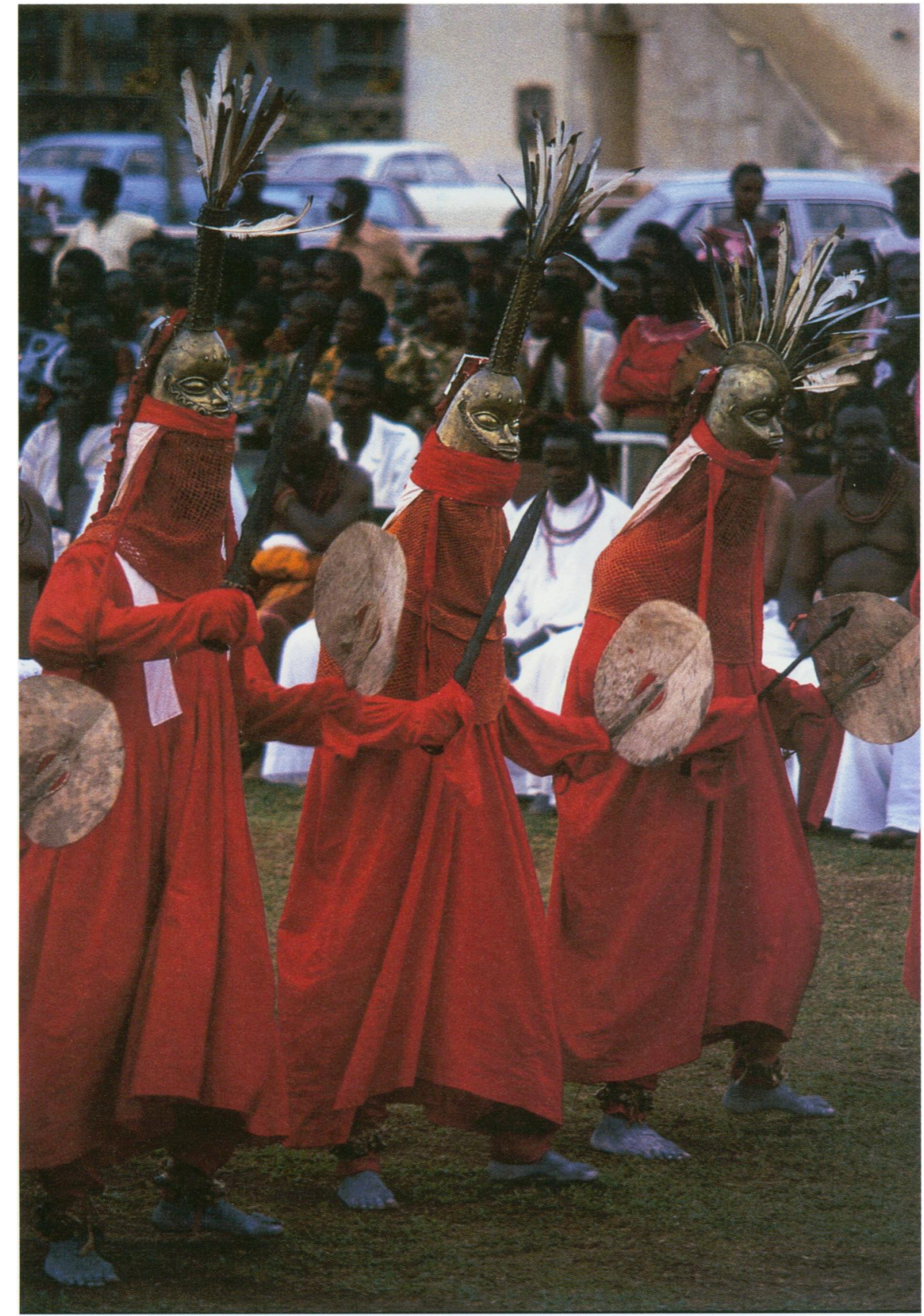

Eresonyen is said to have admired the town's fourteen Ovbo n'Uzala masqueraders. He decided to return with seven (a medicine-connected number used to summon "hot" gods), ${ }^{29}$ giving chiefs Osa and Osuan their dances and songs.

The masquerade's costumes and dance implements, however, owe nothing to Uzala. Three dancers represent males; their headpieces (which sit atop the head, unlike true masks) are capped with long oro projections. Three others represent females with crested hairstyles (Underwood 1949), while one has a very short oro and represents a male spirit-world child, ovbie erimwin (Fig. 7). All have large, staring, iron-inlaid eyes, as well as bared teeth.

The British carried off the eighteenthcentury headpieces in 1897.30 Their
Left: 9. Ododua masqueraders at the Oba's palace. Benin City, 1986. Photo: Joseph Nevadomsky.

Opposite page: 10. Ododua headpiece. Bronze, $70.5 \mathrm{~cm}$ (27.8"). The Walt Disney-Tishman African Art Collection, 1984.AF.051.076.

The female headpieces display the crested coiffures of eighteenth-century court attendants. All have four marks over each eye, but they lack the ikaro and reptiles. The "child" also lacks these, as well as the Uzebu pattern, although he bears the three eye marks of other males. $\mathrm{He}$ is further distinguished by several crescent moons in his hair and by the elephant trunk-hand-a popular eighteenth-century motif-which appears at the corners of his lips.

Most Ododua performers hold either crosses or ufiemwin (iron objects that resemble wrapped arrows) in one hand, and either an agbada sword (males) or a fan (females) in the other. ${ }^{31}$ The "child," who seems to be the group's leader, carries both fan and avalaka. Chief Osuan states that all these implements enable the masqueraders to "go to the unknown forcefully. Generally things in front are seen as evil; these drive it away and let [them] go ahead without problems." The avalaka in particular refers to the deities' power to kill. ${ }^{32}$ As if to reinforce this, the "child's" dress included an abstract sheet-brass ornament in the form of Ofoe, harbinger of death (Bradbury notes: R58).

Ododua headpieces are unlike any other Edo examples, though their form resembles certain riverine masks originated by the ljo and imitated by the Itsekiri, riverine Yoruba, and others, including the Edo of Ughoton. Stylistically they are consistent with other Benin work of the same period, except for the mouth with exposed teeth, a feature uncommon in Edo art and, indeed, in Edo culture. (Teeth are not represented in recent examples, however.) As one elderly man stated, "The mouth and genitals are private. It shows cultured upbringing to cover your mouth." Aristocrats often shield their mouths with handkerchiefs and do not eat in public. The expression "No one sees the teeth with which the ihen deities ate something" associates teeth with privacy and power.

Bared teeth do occur, however, on two face pendants in the Benin Museum (Willett 1973:11), as well as on two bells (Willett 1973:13; Fagg \& Plass 1964:123) and the Tada bronze figure's circular medallions (Eyo \& Willett 1980:149). These examples also include snakes extruding from the nostrils; in Benin this signifies that a native doctor's very breath has the power to destroy enemies. Osun, the personification of medicine, is associated with this imagery. The leaves grasped by the elephant trunk-hand motif 
on the headpiece of the Ododua "child" is also a shorthand reference to Osun, and the moons in his hair further refer to powers of medicinally strong "night people."

However, it is crocodiles (agbaka), not snakes, which emerge from the nostrils of the Ododua heads. The water-avoiding Edo consider them frightening, potent aggressors. Merciless people are called "as sharp as crocodiles (agbaka)." An incantation speaks to the creature's perceived ruthlessness: "When the crocodile catches something, he doesn't leave it."

The identity of the masked spirits remains inconclusive. Their supervisor, Chief Osa, says, "They all have names, but they can't be mentioned. There is rank among the seven." Ben-Amos (1976) proposed that they depicted Ora, his wife Uwen, and their entourage"great magicians who came from Ife with Oranmiyan" - but later (1984) alternatively suggested that they portray "members of the ruling line of Ododua, the father of Oranmiyan and progenitor of this Yoruba dynasty."

The masquerade's name does suggest a Yoruba dynastic connection, but the male headpieces themselves hardly represent monarchs, whether Yoruba or Edo. Minimal ornamentation, crownless heads, and exposed teeth are not found on Edo portrayals of respected monarchs. The females do not have queenly hairstyles, although they do, curiously enough, wear the beaded udahae headband normally seen only on royal men and chiefs. ${ }^{33}$ Although Ben-Amos (1984:75-79) attempts to relate the headpieces' form and function to Yoruba works with royal connotations, the similarities are not particularly strong. ${ }^{34}$

Internal evidence suggests that her earlier hypothesis has more merit, though it is still problematic. The works' iconography does strongly suggest Osun, and one of Ague's prime functions is medicinal strengthening. 35 Identification with Osun specialists would be nearly certain if not for one critical aspect: the presence of females, who are considered medicineneutralizers (Curnow, in press). Perhaps this emphasis on the couple relates to the deity Uwen's fertility concerns. Sexual pairing-exceedingly rare in Benin art, though common elsewhere in Africaimplies duality and complementarity. The presence of these alien concepts constitutes the masquerade's strongest Yoruba links.

The Ododua masquerade may be the only vestige of Ague, but memory, verbal expressions, and artworks attest to the ceremony's historical importance. If these create a somewhat confusing mixture of information, contradictions, and gaps, they at least help illuminate some aspects of the past. Their very variety speaks to the hazards of regarding Ague-and probably other Benin festivals-as static.

Notes, page 93

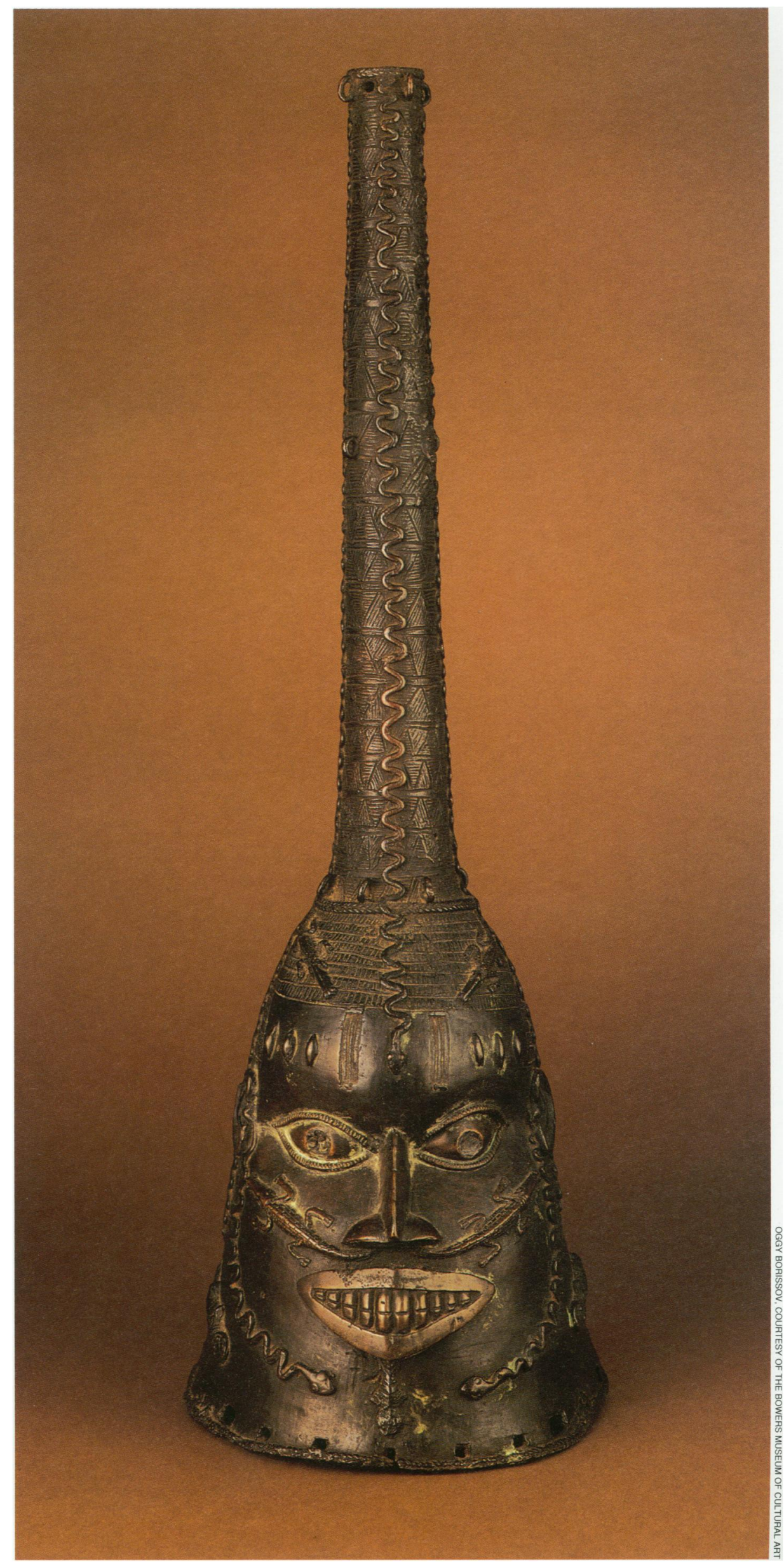


Ben-Amos, Paula. 1975. "Professionals and Amateurs in Benin Court Carving," in African Images: Essays in African Iconology eds. Daniel McCall and Edna Bay. Boston University Papers on Africa, 6. Africana Publishing Co.

Ben-Amos, Paula. 1976. "Men and Animals in Benin Art," Man n.s. 11, 2.

Ben-Amos, Paula Girshick. 1995. The Art of Benin. Rev. ed. London: British Museum Press.

Blackmun, Barbara. 1984. "The Iconography of Carved Altar Tusks from Benin," vols. 1-3. Ph.D. dissertation, UCLA.

Blackmun, Barbara. 1988. "From Trader to Priest in Two Hundred Years: The Transformation of a Foreign Figure on Benin Ivories," Art Journal 47, 2: 128-38.

Blackmun, Barbara. 1990. "Obas' Portraits in Benin," African Arts 23, 3.

Bradbury, R. E. 1959. "Divine Kingship in Benin," Nigeria 62 186-207.

Bradbury, R. E. 1961. “Ezomo's Ikegobo and the Benin Cult of the Hand," Man 129-37.

Bradbury, R. E. 1973. Benin Studies. I.A.I. Ethnographic Survey of Africa Series. London: Oxford University Press.

Cole, Herbert M. 1982. Mbari: Art, and Life Among the Owerri Igbo. Bloomington: Indiana University Press.

Coombes, Annie. 1994. Reinventing Africa: Museums, Material Culture and Popular Imagination in Late Victorian and Edwardian England. New Haven: Yale University Press.

Dark, Philip. 1973. An Introduction to Benin Art and Technology. London: Oxford University Press.

Dark, Philip. 1982. An Illustrated Catalogue of Benin Art. Boston G. K. Hall.

Egharevba, Jacob. 1960. A Short History of Benin. Ibadan: Ibadan University Press. 1st ed. 1934, 2nd ed. 1953.

Ezra, Kate. 1992. Royal Art of Benin: The Perls Collection in the Metropolitan Museum of Art. New York: The Metropolitan Museum of Art.

Fagg, William. 1963. Nigerian Images. London: Lund Humphries.

Fagg, William. 1970. Divine Kingship in Africa. London: British Museum

Giddens, Anthony. 1979. Central Problems in Social Theory: Action, Structures, and Contradiction in Social Analysis. Berkeley: University of California Press.

Gore, Charles. 1995. "Urban Contemporary Shrine Configurations in Benin City, Nigeria." Ph.D. thesis, Dept of Art and Archaeology, School of Oriental and African Studies, Archaeology, School
University of London.

Gore, Charles. 1997. "Casting Identities in Contemporary Benin City," African Arts 30, 3: 54-61.

Gore, Charles and Joseph Nevadomsky. 1997. "Practice and Agency in Mammy Wata Worship in Southern Nigeria," African Arts 30, 2: 60-69

Hawthorn, J. 1994. A Concise Glossary of Contemporary Literary Theory. London: Edward Arnold. 2nd ed.

Igbafe, Philip Aigbona. 1979. Benin under British Administration: The Impact of Colonial Rule on an African Kingdom, 18971938. Atlantic Highlands, NJ: Humanities Press.

Kaplan, Flora. 1993. "Iyoba, the Queen Mother of Benin," Art Kaplan, Flora. 1993. “Iy
History 16, 3: 386-407.

History 16, 3: 386-407. "A Benin Bronze Horseman at the
Karpinski, Peter. 1984. "A Ben Karpinski, Peter. 1984. "A Benin Bronze Horseman at
Merseyside County Museum," African Arts 17, 2: 54-62.

Nevadomsky, Joseph and Daniel Inneh. 1983. "Kingship Succession Rituals in Benin. Part 1: Becoming a Crown Prince," African Arts 17, 1.

Nevadomsky, Joseph. 1984a. "Kingship Succession Rituals in Benin. Part 2: The Big Things," African Arts 17, 2.

Nevadomsky, Joseph. 1984b. "Kingship Succession Rituals in Benin. Part 3: The Coronation of the Oba," African Arts 17, 3. Nevadomsky, Joseph. 1986. "The Benin Bronze Horseman as the Ata of Idah," African Arts 19, 4 .

Nevadomsky, Joseph. 1997. "Studies of Benin Art and Material Culture, 1897-1997," African Arts 30, 3.

Onobrakpeya, Bruce. 1985. Symbols of Ancestral Groves

Onobrakpeya, Bruce. 1988. Sahelian Masquerades.

Onobrakpeya, Bruce. 1992. The Spirit in Ascent.

Picton, John and John Mack. 1989. African Textiles. London: British Museum Publications. 1st ed. 1979.

Rosen, Norma. 1989. "Chalk Iconography in Olokun Worship," African Arts 22, 3, 44-53.

Ryder, A. F. C. 1969. Benin and the Europeans. London: Longmans.

\section{COOTE \& EDWARDS: Notes, from page 35}

We should like to thank the following for their help in gathering information about the material discussed here: Nigel Barley (Assistant Keeper, Department of Ethnography, British Museum, London), Claire Brown (National Army Museum, Museum, London), Claire Brown (National Army Museum, British Museum, London), Philip J. C. Dark, Marjorie Harvey (Manager of Exhibitions and Design, High Museum of Art Atlanta), Liv Henson (Photographic Services, Cincinnati Ar Museum), Alisa LaGamma (Assistant Curator, Department of the Arts of Africa, Oceania and the Americas, The Metropolitan Museum of Art, New York), Malcolm McLeod (Director, Hunterian Museum, Glasgow), Claire Mason (Museum Collection Manager, Maidstone Museum and Art Gallery), and Louise Tythacott (Curator of Ethnology, Liverpool Museum, National Galleries and Museums on Merseyside). Paula Girshick Ben-Amos, Schuyler Jones, and Alison Petch kindly read previous drafts of this article and Alison Petch kindly read previous drafts of this article and
made helpful comments. We are also grateful to Simon made helpful comments. We are also grateful to Simon
Dumas and the Dumas Egerton Trust for their cooperation.
1. For a good example of what can be done, see Peter Karpinski's interesting examination (1984) of the way the Swainson photographs from 1892 were circulated and used in the press in the context of the events of 1897.

2. Confusingly, he goes on "and by the courtesy of the proprietors of the Illustrated London News" (Bacon 1897:7). This could be taken to mean that only some of the illustrations in his book are from his own sketches, the others being copied from those reproduced in the Illustrated London News. It could also be taken to mean that Overend's engravings reproduced in the Illustrated London News were all copied from Bacon's sketches. If this were so it would cast doubt on Annie Coombes's detailed critique of the illustrations in Bacon's book (Coombes 1994:20-21).

3. As the lists in Dark 1982 make clear (see references to Egerton in \$2.3 "Collections of Benin Art"), Egerton took from Benin more than the thirty-three items presently held at the Museum. Other items formerly in the Egerton collection are to be found in the Metropolitan Museum of Art, the British Museum, and elsewhere. Many of the pieces in the original collection were illustrated in von Luschan 1968 (1919). A number of those now held at the Pitt Rivers Museum are illustrated in Mowat 1991

4. A number of scholars had access to the Egerton collection including the watercolors, before its deposit at the Pitt Rivers Museum. We understand from Philip Dark that William Fagg apparently photographed the collection in 1955 and 1958 (see the illustration references for the Egerton material in Dark 1982). From the records of the loan to Maidstone Museum \& Art Gallery, it is clear that Fagg examined the collection in 1975 and again in 1984 for Christie's, while Malcolm McLeod and Nigel Barley examined the collection in February 1983, though they tell us they have no memory of seeing the watercolors on that occasion. (For relevant correspondence and copies of Maidstone's records, see PRM file RDF 1991.13.)

5. Robert Home had access to the Egerton papers in prepar5. Robert Home had access to the Egerton pap
ing his account of the expedition (1982:132).

ing his account of the expedition (1982:132).
6 . The altarpiece at the Museum (PRM: 1991.13.25) has been illustrated a number of times (e.g., see von Luschan 1968: fig. 459; Mowat 1991: fig. 13; Coote 1995:2)

7. The images in question are PRM: B8.15e (Ben-Amos 1980: fig. 5) and PRM: B8.15k, Figure 5 here (Ben-Amos 1980: fig. 42). 8. Fagg borrowed two objects from him for the Museum's "Art from the Guinea Coast" exhibition (Fagg 1965): a terracotta head (no. 67 in the exhibition; see Fagg 1965:10) and a side-blown ivory horn" (no. 71 in the exhibition; see Fagg side-blown ivory horn" (no. 71 in the exhibition; see Fagg
1965:11). The head was later acquired (PRM 1967.45.1). In 1965:11). The head was later acquired (PRM 1967.45.1). In
August 1966 Nevins sent Fagg various papers relating to his time in Nigeria, and Fagg collected more papers from him in February or March 1968

9. The correspondence with and about Nevins referred to here is held in various files at the Museum: RDF 1967.45.1 RDF (Objects) "Nevins"; RDF (Manuscripts) "Nevins."

10. These notes were considered sufficiently important in 1957 for the Department of Antiquities in Lagos to arrange to have them copied.

11. The album has suffered from being kept (or left) in damp conditions, as well as from insect damage and chemical deterioration, suggesting that it might well have been in West Africa for some considerable time.

12. Henry Ling Roth died in 1926, but it is not impossible that the photographs were given by him to Henry Balfour some time before then. Balfour may then have passed them on to the Museum after 1931, or they may have passed to the Museum on his death in 1939. A substantial amount of material came to the Museum in this way, not all of it properly accessioned at the time. Roth would certainly have been in touch with Balfour, and he is recorded as having donated material to the Museum on several occasions.

13. Contact prints are made not with an enlarger but by direct contact of the negative on the photographic paper; thus the negative and the print are the same size. As today, cameras in the late nineteenth century took different plate sizes. Although some were convertible, it does not look as if this was the case here, as the lens quality is different.

was Image number 5 in the Granville album, "Ivory Found in 14. Image number 5 in the Granville album, "Ivory Found in
the City" (Fig. 6, top right here), and image number 7, "One of the City" (Fig. 6, top right here), and image number 7, "One of
the Entrances to the King's Compound" (Fig. 7, top left here) the Entrances to the King's Compound" (Fig. 7, top left here), both appear in Robert Home's City of Blood Revisited (1982). Home fails to source individually the illustrations in his book, but given that he makes specific reference to having reproduced images from the Burrows album (Home 1982:132), it seems reasonable to assume that this is the origin of these particular images. We have

ine the Burrows album.

15. This is number 17 in the Granville album, where it is captioned "Ivory." The British Museum print of this same image has been published by Dark (1973: pl. 9, fig. 20).

16. PRM: B8.15d was published as figure 166 on page 170 (see also Fig. 10 here); PRM: B8.15e as figure 168 on page 174 (see also Fig. 8 here); PRM: B8.15f as figure 169 on page 176; PRM $\mathrm{B} 8.15 \mathrm{~g}$ as figure 73 on page 67 ; PRM: $\mathrm{B} 8.15 \mathrm{~h}$ as figure 75 on page 70; PRM: B8.15i as figure 193 on page 191; PRM: B8.15j as figure 167 on page 172 (see also Fig. 9 here); and PRM: B8.15l as figure 72 on page 64

17. Earlier, Roth refers to the punitive expedition as "the little war we waged" (1903: vi).

18. The West African climate is not favorable for the longevity of gelatin-based photographic emulsions.

19. For an examination of such networks see Thomas Richards's The Imperial Archive (1993).

20. The three are PRM: B8.15d, PRM: B8.15h, and PRM: B8.15l, reproduced by von Luschan as figures 4,5 , and 8 respectively (von Luschan 1968:3-5).

References cited

Bacon, R. H. 1897. Benin: The City of Blood. London: Arnold. Ben-Amos, Paula. 1980. The Art of Benin. London: Thames \& Hudson. Rev. ed. 1995.

Boisragon, Alan. 1898. The Benin Massacre. London: Metheun Coombes, Annie E. 1994. Reinventing Africa: Museums, Material Culture and Popular Imagination in Late Victorian and Edwardian England. New Haven, CT: Yale University Press. Coote, Jeremy. 1995. "African Collections in the British Isles," Museum News 63:2-3.

Dapper, Olfert. 1668. Naukeurige Beschrijvinge der Afrikaensche Gewesten. Amsterdam.

Dark, Philip J. C. 1973. An Introduction to Benin Art and Technology. Oxford: Clarendon Press.

Dark, Philip J. C. 1982. An Illustrated Catalogue of Benin Art. Boston: G. K. Hall

De Bry, Johann Israel. 1604. India Orientalis. Pt. 6. Frankfurt. Dening, Greg. 1988. History's Anthropology: The Death of William Gooch. Association for Social Anthropology in Oceania, Special Publications 2. Lanham, MD: University Press of America.

Fagg, Bernard. 1965. Art from the Guinea Coast. Pitt Rivers Museum Illustrated Catalogue 1. Oxford: Pitt Rivers Museum, University of Oxford.

Fagg, William. 1977. "The Great Belzoni," West Africa 3130 (4 July):1330-31.

Home, Robert. 1982. City of Blood Revisited: A New Look at the Benin Expedition of 1897. London: Rex Collings.

Kaplan, Flora S. 1991. "Benin Art Revisited: Photographs and Museum Collections," Visual Anthropology 4:117-45.

Karpinski, Peter. 1984. "A Benin Bronze Horseman at the Merseyside County Museum," African Arts 17, 2:54-62, 88-89. Miles, G. L. P. 1938. "Additional Notes on Benin Altars and Compounds," Ethnologia Cranmorensis 3: 5-8, frontispiece (p. 2). Mowat, Linda. 1991. Symbols of Kings: Benin Art at the Pitt Rivers Museum. Oxford: Pitt Rivers Museum, University of Oxford. Richards, Thomas. 1993. The Imperial Archive: Knowledge and the Fantasy of Empire. London: Verso.

Roth, H. Ling. 1903. Great Benin: Its Customs, Art and Horrors. Halifax: F. King \& Sons.

von Luschan, Felix. 1968. Die Altertümer von Benin. New York: Hacker Art Books. 1st pub. 1919.

GORE: References cited, from page 45

The following lists the works of R. E. Bradbury:

1951-52. "A Series: Field Notes, Benin City and Surroundings." University of Birmingham Library. Birmingham, England.

1953-54. "U Series: Field Notes from Benin." University of Birmingham Library.

957-61. "BS Series. Benin Scheme Fieldnotes." University of Birmingham Library.

N.d. "R Series: Field Notes from Benin." University of Birmingham Library.

1962 (with Frank Speed). Benin Kingship Rituals. 35 mm film. London: London Colour Services.

1957. The Benin Kingdom and the Edo-Speaking Peoples of Southern Nigeria, together $w /$ a Section on the Itsekiri. I.A.I. Ethnographic Survey of Africa Series, pt. 13. London: Oxford University Press.

957. "The Social Structure of Benin with Special Reference to the Political-Ritual Organization (the Village Community." Ph.D. thesis, University of London.

1959. "Chronological Problems in the Study of Benin History," Journal of the Historical Society of Nigeria 1, 4 1959. "Divine Kingship in Benin," Nigeria 62:187-207.

1961. "Ezomo's Ikegebo and the Benin Cult of the Hand, Man 61, 165:129-38.

967. "The Kingdom of Benin," West African Kingdoms in the Nineteenth Century, eds. Daryll Forde and Phyllis M. Kaberry. London, pp. 1-35. Oxford University Press for the International African Institute.

969. "Patrimonialism and Gerontocracy in Benin Political Culture," Man in Africa, eds. Mary Douglas and Phyllis M. Kaberry, pp. 17-36. London: Tavistock Publications. 1973. Benin Studies. I.A.I. Ethnographic Survey of Africa Series. London: Oxford University Press.

\section{CURNOW: Notes, from page 53}

This paper is based on research conducted in Benin City from 1992 to 1997, partially funded by the National Endowment for the Humanities and Cleveland State University. My deepest thanks go to Omo n'Oba n'Edo Erediauwa, the Oba of Benin, for his gracious research permission and encouragement, and also for the assistance of his Chiefs Osa, Osuan, Obasogie, Ohuoba, Esogban, Eson, Ogiamien, Aragua, Ine Igbesanmwan, Obamwonyi of Ogbelaka, and the Ihama of Ihogbe, as well as James Ihama of Igun, Mr. Ohomina, Ihpemwosa Osemwegie, Gregory Airihenbuwa, Mr. Omomon of Enisen, and Mrs. Victoria Ekhator. Many thanks also to Paula Girshick Ben-Amos, Barbara Blackmun, Joseph 
1. Oba gha rie oba oghi domwin iyi ogbon.

2. New Yam festivities are common in many parts of southern Nigeria. Some Benin ceremonial traits were shared with the neighboring Igbo. As Pita Ejiofor notes (1985:33-34), many
Igbo would not eat new yam until their priests had consumed a ritual meal of specially planted tubers.

3. Royals offer only blood sacrifices to their ancestral shrines, but present new yams to many deities and spirits. In his sensationalistic publication, Jacolliot discussed Benin's New Yam festival (1880:40-43). He claimed human blood was poured into a liva ( basin of food, creating a protective charm for the Oba without it, he was exposed to terrible dangers, including poswithout it, he was exposed to terrible dangers, including possession by "Lolouc" (Olokun). Jacolliot also maintained that the
Oba and chiefs ate new yam at the market (most unlikely, since Oba and chiefs ate new yam at the market (most unlikely, since
the Oba never eats in public), and further claimed the ruler traveled to the Benin River for a purification bath, there sacrificing a goat and ram as scapegoats for all Benin

4. Ague's acknowledgment of this fasting is a curious contradiction of tradition. To suggest that the Oba eats food is conventionally forbidden (he is said to consume chalk); if visitors call on a chief during mealtime, they are told only that he is "busy." The fasting was not total. Participants ate old crops (including the yam variety known as emile or ikpendeghedeghe), as well as melon, garri, beans, corn pudding, and dried "walnuts."

5. The Iwoki palace guild, concerned with astronomy, scheduled festival openings for the day before New Moon and closings on the following New Moon. A festival thus began in one month, continued into a second, and closed (with the New Moon) in a third. A "three-month" cerem

was equivalent to one Western month. 6. This fixed venue gave rise to the saying "Ague does not exceed Ogun" (Ague $i$ hien Oguan), referring to places visited
at regular times.

7. Although this illness was considered a supernatural punishment, its origins may have been organic. Benin yams ("red yams," or ikpen) are dried on racks two to three months after harvest, since eating freshly dug yams is believed to cause dysentery or fever.

8. The High God Osanobua's priest (Ohensa) distributed the umanague. While Egharevba ("Benin Museum Catalogue" in Bradbury notes:R67) and Melzian (1937:101) suggested the badges were worn at the commencement of fasting, some sources said they were only awarded to successful participants. Wedge-shaped umanague are illustrated in von Luschan 1919: drawing C, a-f. Ewa guild members and Ohensa are known to have worn crosses up until this century. In 1897 the British found several small crosses "like Catholics wear" (Roth 1968 [1903]:14) in the palace. Ward-Price said the Oba (Roth 1968 [1903]:14) in the palace. Ward-Price said the Oba
wore a brass cross around his neck, pressing it to his forehead wore a brass cross around his neck, pressing
during daily morning prayers (1939:238).

9. Rhunmwunde were o ma setin, o ma saba; and Umanague zo. 10 . Some accounts say Ora was an $o b o$, or medicine specialist whose wife's name was Uwen; they came from Ife and were later deified. Other versions suggest they were brought from Ife as deities incarnated by objects; some traits suggest they may personify male and female principles. Despite their ostensible Ife origins, they are connected with Usen, near Benin's border with Yorubaland, where Chief Osuan's Uwen grove is duplicated. Oba Akenzua II said Usen is actually Uwen's principal seat (Bradbury notes 1958: BS96), and Uwen's principal seat (Bradbury notes 1958: BS96), and
Ewuare is said to have been initiated into the cult there. Igbo soldiers who entered the Usen grove during the Nigerian Civil War are believed to have emerged pregnant.

11. Agbon khon $y^{\prime}$ omen erimwin na khon y'ukhuerehe.

12. Osa $v b^{\prime}$ Osuan o ren vbo rre uwe omen.

13. Ugie ne oba kiere ere Osa vb'Osuan yo. Chief Osuan also bears the appellations Doloro ("owner/leader of secrets") and Osuan neo bu'Egie ("Osuan, your presence is needed at the festival"). Blackmun notes these chiefs' sacrificial duties (1984:52, 65, 79, 265-66, 269, passim).

14. Chief Osa's quote: Osa gb'omwan re; ovbie re o rie omwan buebue. Ebo n'Edo praise name: Ebo nei rie okhonmwon.

15. I hon ebo ra, ebo we mwen miniminimini, $i$ na vbe we miniminimini.

16. Ugbague had served as a holding place for sacrificial victims and slaves since Ewuare's time.

17. In addition to the Lagos plaque shown in Figure 2, these are as follows: National Museum, Lagos; British Museum 98.1 15.23 and 98.1-15.26; Hamburgisches Museum für Völkerkunde C2894 and C2897; and Pitt Rivers Museum, Oxford.

18. This curtailment is never accorded Edo figures, and suggest a conscious application of "Otherness" (see Curnow 1990).

19. Numerous pieces show the fish-legged Oba supported by kneeling chiefs, as he is on the Ague plaques; their frequent three-quarter poses suggest that the Ague plaques may have been prototypes (see an early example in von Luschan been prototypes (see an early example in von Luschan 1919:284, abb. 426 and comparable later pieces in von Luschan 1919:285, abb. 424, Dark \& Forman 1960:40, and elsewhere).
20. Ben-Amos states that the Oba's ise-vberigho-including a paddle-shaped brass wand, an avalaka, and other objects - are kept there. Umanague badges are also stored in Iwogun when not in use (Egharevba, "Benin Museum Catalogue" in Bradbury notes: R67).

21. The Ooton, drawn from Osa and Osuan's followers as well as from the Ogbelaka, joined the Isienmwero and other Ogbelaka members in "night walking" (okhian ason or akhiason, often called okerison in the literature). Citizens who ventured outdoors during evening curfews risked death from these "night walkers"; the phrase "I'm Osuan's son" acted as these "night walkers"; the phrase "I'm Osuan's son" acted as
a password. "Night walkers" were meant to control thieves and ruffians, and were rewarded with chieftaincies

22. The standing figures' hands are cast as if to hold something; any unattached staffs have since disappeared. 23. Frank Willett suggested these figures represented courtiers who traveled to Ife regarding the Benin monarch's confirmation (1967:29); Dark supported this idea (1973:99). Ben-Amos proposed an Ohensa identification (1995:56).

24. See Nevadomsky 1987 for a good analysis of the cross umanague, since the Ebo n'Edo attendants are closely involved with Ague, and the Ohensa distributed the umanague.

with Ague, and the Ohensa distributed the umanague. 25. There seems to be a connection between the Ebo n'Edo and
Ogun, deity of war. They share the same palace chamber, and Ogun, deity of war. They share the same palace chamber, and
certain praise names for Uwen and Ora or their priests are war certain praise names for Uwen and Ora or their priests are war
related. One appellation for the Ebo $n^{\prime}$ Edo is ugbe nowewe, or "enemy blaster" (owewe is a type of firearm, while ugbe is a stone, suggesting a cannon). Uwen is praised by "Uwen has destroyed enemies/barbarians" (Uwen gb'ete), an accolade said to date from her role in Esigie's victory over Idah. Chiefs Osa and Osuan accompanied the Oba when he went to battle: "If the Oba is not preparing for war, Osa and Osuan don't go" (Oba ma mue egbe okuo n'iweva $i$ yo). The Ewa feature on an Ogun gong (Roth 1968 [1903]:56, figs. 61, 64). Their leader, Chief Ohuoba, holds this type of instrument annually at the Esigie-instituted Emobo ceremony, and it also appears at coronations (Nevadomsky 1984:52). The Reiss-Museum plaque nations (Nevadomsky 1984:52). The Reiss-Museum plaque
(Fig. 4) may illustrate a link between Ague, the Ewa, and the Idah war; it shows a high-ranking soldier with a kneeling, praying Ewa and two Portuguese half-figures. Chief Osuan, Uwen's priest, says this war increased his title.

26. Castration's ties to Idah are reinforced by the saying " $A$ ren neo wa omwan vbe Ighan," or "Nobody knows who castrates somebody in Ighan (Idah)."

27. For leopard imagery in Benin, see Blackmun 1991. Boston discusses Igala leopard associations, which include mourning dead leopards like royals and spotting royal shrouds (1968:50-51).

28. Eresonyen he mien eke muen Ague Osa go yi.

29. Eresonyen's trip to Uzala is said to have been war related. This is curious; supposedly, Ehengbuda was the last Oba to go to war, and royal sequestration in the palace was nearly complete after his time. Perhaps this confinement was only an accepted fiction, like the "complete" ban on contact between
the Oba and his heir or the supposed killing of all Queen the Oba and his heir, or the supposed killing of all Queen Mothers before Esigie.

30. Besides the Disney-Tishman example (Fig. 10), the eighteenth-century male headpieces are in the British Museum and the National Museum, Lagos. Two female headpieces are in the British Museum; I have not been able to track down the
third. The "child" is now in Berlin's Museum für Völkerkunde. third. The "child" is now in Berlin's Museum für Völkerkunde. 31. The dance tools are clearly evident in the Frank Speed and
R. E. Bradbury film Benin Kingship Rituals, but the 1989 R. E. Bradbury film Benin Kingship Rituals, but the 1989
Ododua Masquerade video shows ufiemwin, which resemble Ododua Masquerade video shows
umomo, another type of hammer.

umomo, another type of hammer.
32. In times past, when the performance was at night, it was widely believed that even "strong" (medicinally reinforced) spectators would remain only until the fifth of seven songs was sung: "If you went further than that, they say something will happen-you'll be done away with."

33. The Iyoba currently owns udahae, while the Oba's senior daughter (and perhaps his second daughter) receives it at her wedding.

34. Ben-Amos notes that in 1981, Blackmun was also told that
her weding. 34. Ben-Amos notes that in 1981, Blackmun was also told that
the masks "represent kings in the ruling line of Ododua" the masks "represent kings in the ruling line of Ododua"
(Ben-Amos 1984:79). Formal and symbolic correlations with (Ben-Amos 1984:79). Formal and symbolic correlations with
Yoruba examples are unconvincing. While the Iperu crown does have a stem-on-cone structure, its style and iconography are unconnected to the Benin works; the brass Oyo masks may have a protective function, but so do a great many other African masks - no specific analogies seem to exist. If Ododua imagery is really preoccupied with "cosmic order/disorder," as she suggests - and this is by no means certain, as the mudfish and eben which appear on two masks do not fit this category-perhaps land purity/pollution is the cause.

35. The masquerade's combination of fertility and Osun-relat35. The masquerade's combination of fertility and Osun-relat-
ed issues is standard for the Ebo $n^{\prime} E d o$; the Eghute festival ed issues is standard for the Ebo n'Edo; the Eghute festival
also associated the two. Headed by Chief Osuan, this cerealso associated the two. Headed by Chief Osuan, this cere-
mony's objectives were the revival and reactivation of the Oba's Osun, as well as the fruitfulness of both plants and women. Benin medicine is generally regenerated through purification at one level or another. At Eghute, the land itsel is cleansed by rites requiring all pregnant women to go beyond the city walls for its duration.

References cited

Ben-Amos, Paula Girshick. 1976. "Men and Animals in Benin Art," Man n.s. 11, 2.

Ben-Amos, Paula. 1984. "Royal Art and Ideology in EighteenthCentury Benin," lowa Studies in African Art 1:67-86.

Ben-Amos, Paula Girshick. 1995. The Art of Benin. Rev. ed. London: British Museum Press.

Blackmun, Barbara. 1984. "The Iconography of Carved Ivory Tusks from Benin, Nigeria." Ph.D. dissertation, UCLA. Blackmun, Barbara. 1991. "The Face of the Leopard: Its
Significance in Benin Court Art," Allen Memorial Art Museum Bulletin 44, 2:24-33.

Boston, J. S. 1968. The Igala Kingdom. Ibadan: Oxford University Press.

Bradbury, R. E. Unpublished notes. University of Birmingham Library.

Curnow, Kathy. 1990. "Alien or Accepted: African Perspectives Curnow, Kathy. 1990. "Alien or Accepted: African Perspectives
on the Western "Other" in 15th and 16th Century Art,"

Society for Visual Anthropology Review 6, 1:38-44.

Curnow, Kathy. In press. "A Gentleman and His Prestige: Benin's Ideal Man," Art Journal.

Dark, Philip J. C. 1973. An Introduction to Benin Art and Technology. Oxford: Clarendon Press.

Dark, Philip J. C. 1982. Illustrated Catalogue of Benin Art. Boston: G.K. Hall.

Dark, Philip J. C., W. Forman, and B. Forman. 1960. Benin Art. London: Hamlyn.

Egharevba, Jacob U. 1934. Benin Law and Custom. Benin City.

Egharevba, Jacob U. 1968. A Short History of Benin. 4th ed. Ibadan: Ibadan University Press.

Ejiofor, Pita N. O. 1985. "New Yam Festival in Anambra State," Ugo 1 (Dec.):30-37.

Eyo, Ekpo and Frank Willett. 1980. Treasures of Ancient Nigeria. New York: Knopf.

Fagg, William B. 1963. Nigerian Images. London: Percy Lund, Humphries \& Co.

Fagg, William and Margaret Plass. 1964. African Sculpture: An Anthology. London: Studio Vista.

Jacolliot, Louis. 1880. Voyage aux Pays Mystérieux: Yebou, Borgou, Niger. Paris: Marpon \& Flammarion.

von Luschan, Felix. 1919. Die Altertümer von Benin. Berlin: Museum für Völkerkunde.

Melzian, Hans. 1937. A Concise Dictionary of the Bini Language of Southern Nigeria. London: Kegan Paul, Trench, Trubner \& Co. Melzian, Hans. 1959. "Zum Festkalender von Benin," in Melzian, Hans. 1959. "Zum Festkalender von Benin
Afrikanistische Studien, pp. 87-107, ed. Lukas. Berlin.

Nevadomsky, Joseph. 1984. "Kingship Succession Rituals of Benin, Part 3: The Coronation of the Oba," African Arts 17, 3:48-57.

Nevadomsky, Joseph. 1987. "Brass Cocks and Wooden Hens in Benin Art," Baessler-Archiv n.f. 35, 1:221-247.

Nevins, H. N. 1928. "Intelligence Report, Benin Division, Benin Province."

Ododua Masquerade. 1989. Videorecording. Benin City: Oba's Palace.

Roth, Henry Ling. 1968. Great Benin: Its Customs, Art and Horrors. London: Routledge \& Kegan Paul. 1st pub. 1903. Ryder, A. F. C. 1969. Benin and the Europeans 1485-1897. London: Longman, Green \& Co.

Speed, Frank and R. E. Bradbury. 1962. Benin Kingship Rituals. $35 \mathrm{~mm}$ film. London: London Colour Services.

Thomas, Northcote W. 1918. "Agricultural Rites," Man 18, 75:138-42.

Underwood, Leon. 1949. Bronzes of West Africa. London: Tiranti. Ward-Price, Henry Lewis. 1939. Dark Subjects. London: Jarrolds.

Willett, Frank. 1967. Ife in the History of West African Sculpture. London: Thames \& Hudson

Willett, Frank. 1973. "The Benin Museum Collection," African Arts 6, 4:8-17.

\section{NEVADOMSKY: References cited, from page 63}

Beier, Ulli. 1968. Contemporary Art in Africa. New York: Praeger Ben-Amos, Paula Girshick. 1971. "Social Change in the Organization of Wood Carving in Benin City, Nigeria." Ph.D. dissertation, Indiana University.

Ben-Amos, Paula Girshick. 1975. "Professionals and Amateurs in Benin Court Carving," in African Images: Essays in African Iconology, eds. D. McCall and E. Bay, pp. 170-89. Boston: Boston University Papers on Africa, 6 . Ben-Amos, Paula Girshick. 1976. "A la Recherche du Temps Perdu: On Being an Ebony Carver in Benin," in Ethnic and Tourist Arts: Cultural Expressions from the 4th World, ed. N. Graburn, pp. 320-33. Berkeley and Los Angeles: University of California Press.

Ben-Amos, Paula Girshick. 1978. "Owina n'Ido: Royal Weavers of Benin," African Arts 11, 4:49-53.

Ben-Amos, Paula Girshick. 1995. The Art of Benin. London: British Museum Press. Rev. ed.

Blackmun, Barbara. 1997. “Continuity and Change: The Ivories of Ovonramwen and Eweka II," African Arts 30, 3:68-79. the Hand, Man 61, 165:129-38.

Cosentino, Donald. 1991. "Afrokitsch," in Africa Explores: 20th Century Art, ed. Susan Vogel, pp. 240-55. Munich: Prestel. Deliss, Clémentine. 1995. Seven Stories about Modern Art in Africa. Paris: Flammarion.

Egonwa, Osa D. 1994. African Art: A Contemporary Source Book. Benin City: Osasu Publishers.

Fabian, Johannes. 1978. "Popular Culture in Africa: Findings and Conjectures," Africa 48, 4:315-34.

Fagg, William. 1968. African Tribal Images: Katherine White Reswick Collection. Cleveland: Cleveland Museum of Art. Gore, Charles. 1997. "Casting Identities in Contemporary Benin Gore, Charles. 1997. "Casting Identiti
City," African Arts 30, 3:54-61.

Gore, Charles and Joseph Nevadomsky. 1997. "Practice and Agency in Mammy Wata Worship in Southern Nigeria," African Arts 30, 2:60-69.

Hess, Catherine. 1983. "Unconventional Carving: Stools and Coconut Shells," in The Art of Power, the Power of Art: Studies in Benin Iconography, eds. P. Ben-Amos and A. Rubin, pp. 41-48. Los Angeles: Museum of Cultural History, UCLA. Kelly, Bernice and Janet Stanley. 1993. Nigerian

Kennedy, Jean. 1992. New Currents, Ancient Rivers: Contemp- 